\title{
Factors Affecting the Competitiveness of VietNam Aquatic Exporters: Empirical Evidence in an Giang Province
}

\author{
NGUYEN HUU PHU ${ }^{1}$, LE DUC TOAN ${ }^{1}$, HO THI PHI YEN ${ }^{2}$, DOAN QUOC BAO 3 \\ ${ }^{1}$ Board of Provost, Graduate School, Duy Tan University, \\ 03 Quang Trung Street, Da Nang City, 550000, VIETNAM \\ ${ }^{2}$ Faculty of Accounting, Hospitality \& Tourism Institute, Duy Tan University, \\ 03 Quang Trung Street, Da Nang City, 550000, VIETNAM \\ ${ }^{3}$ Faculty of Tourism and Economics, Kien Giang University, \\ 320A National Highway 61 - Kiên Giang Province, VIETNAM
}

\begin{abstract}
Viet Nam now is one of the most dynamic emerging countries in East Asia region. Viet Nam is considered as one of the largest aquatic exporting countries in the world. Most of aquatic exporters are in Mekong Delta. An Giang Province is located in this region. This study aims to verify the 10 components which constitute the competitiveness of aquatic exporters in An Giang Province by SPSS 22.0. Through Cronbach's Alpha accreditation, exploratory factor EFA, confirmatory factor CFA, structural equation model SEM were analyzed $\mathrm{t} \mathrm{o}$ offer proposals and recommendations in order to help the aquatic exporters improve their competitiveness in the international market.
\end{abstract}

Keywords: competitiveness, factors affecting, aquatic export, Vietnam.

Received: October 5, 2019. Revised: April 17, 2020. Accepted: May 4, 2020. Published: May 11, 2020.

\section{Introduction}

Aquatic export which is one of four major export items in Vietnam has brought considerable foreign currency for the country. Recently, aquatic export not only has achieved dramatic development, but also made Vietnam become one of the top powerful countries in aquatic export. However, there are still difficulties in aquatic export in Vietnam in general and in An Giang Province in particular. Overcoming those difficulties and challenges requires a cooperation among the government, enterprises and farmer households.

\subsection{Concepts of Competitiveness}

According to Aldington Report (1985): "A competitive enterprise can produce products and services with outstanding quality and lower prices in comparison with domestic and international competitors. Competitiveness means to achieve long-term profit for the company and to guarantee incomes for workers and business owners. "

Jean Louis MUCHIELLI (2002) stated that the term "competitiveness" derives from Latin Competere which means meeting at a point, coping with the competition with the others. Currently, the terms "competitiveness", "capacity of competing" and "ability to compete" are used a lot in economic fields in Vietnam.

Since in English three phrases above mean "competitiveness", they can be used interchangeably. A precise definition for this concept remains a controversial issue. According to M.Porter, no definition of competitiveness has been recognized universally. Here are some definitions of competitiveness:

According to Sanchez \& Heence (1996, 2004), the competitiveness of businesses relies on their ability to combine their resources to create competitive advantages. "The competitiveness of a company is its ability to maintain, implement and coordinate the resources and capabilities in ways that help the company achieve its goals."

According to Bach Thu Cuong (2002) in the book about the global competition, competitiveness is "the capacity of a business or an industry, a country of not being defeated in the economic capacity by other businesses, other industries, other countries ". According to a research by Ramasamy (1995) in Singapore, competitiveness is the ability to increase market share, profit and to maintain competitiveness in a long time.

In summary, the competitiveness is the ability to control the advantages quite better than the opponent. The concept of competitiveness is used not only for the rivalry among the products of the enterprises, among businesses but also for the 
competitiveness among countries in the international competitive environment.

\subsection{Factors Affecting Competitiveness}

Currently, there are four basic methods to evaluate and analyze the competitiveness of businesses: (1) using the SWOT matrix, (2) using the diamond model of Michael Porter, (3) using Thompson-Strickland method and (4) using the competitive matrix method. In the scope of this study, the author bases on the Thompson Strickland method to identify factors affecting the competitiveness. This is the original model.

According to Thompson - Strickland method, there are main factors (Internal and external factors) affecting the enterprises' competitiveness. They include:

1) Administration capacity;

2) Capacity of researching, analyzing and forecasting the domestic and foreign markets ...;

3) Capacity of finding customers and trusted partners to do bus iness effectively with the enterprises;

4) Capacity of producing competitive goods in domestic and international markets...;

5) Capacity to organize export, ... (purchasing, selling, transporting goods, ...);

6) Capacity of international payment;

7) Capacity of handling international commercial disputes quickly and effectively ...;

8) The technological factors such as capacity of research in technology, innovation, use of information technology ...;

9) Factors related to human resources: qualified manpower with high professional skills, key of management quality, experts in product design or important technology ...;

10) Factors related to corporate culture;

11) Factors related to the capacity of adapting and administering changes;

12) The financial factors;

13) Factors related to the image, reputation (brand name);

14) Capacity of competing on price and costs.

\section{Conceptual Framework Research Hypotheses}

\subsection{Conceptual Framework}

Basing on Thompson - Strickland method, we choose 9 factors affecting the enterprises' competitiveness that are suitable for Vietnam condition, and add a new factor to measure factors affecting the aquatic exporters' competitiveness in An Giang Province. They are: capacity of marketing, administration, price, finance, brand name, products, human resources, business development relations, technology and logistics (new factor). It is according with previous studies of Bui Duc Tuan (2010), Tran The Hoang (2011), Nguyen Thanh Long (2016), Tran Van Dat (2016), Moon et al. (1998), Jayasekhar Somasekharan, Harilar, k. N \& Parameswaran M (2012), Gary W. William \& Oral Capps et al. (2017).

\section{Research model to propose aquatic exporters'} competitiveness in An Giang Province

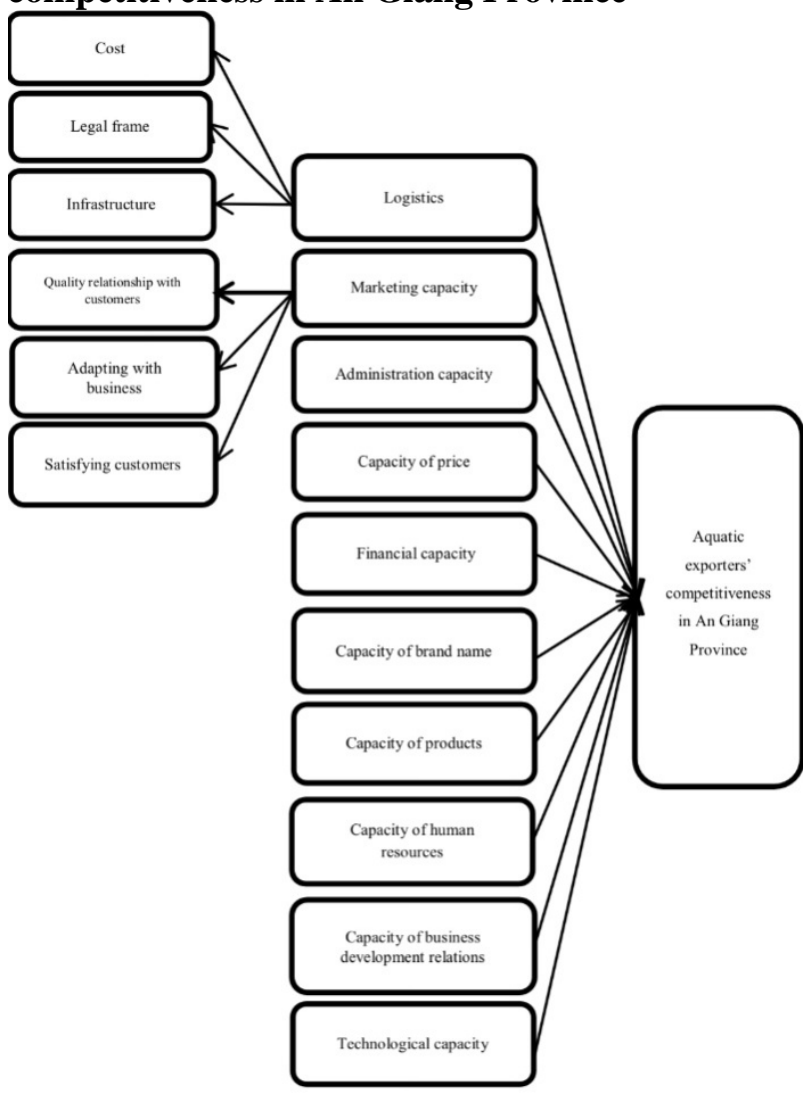

Diagram 1: Research model to propose aquatic exporters' competitiveness in An Giang Province

\subsection{Research Hypotheses \\ Logistics}

The term "logistics" originally came from military with the meaning of supply and transportation or resupply. According to the U.S. Council of Logistics Management - CLM, "Logistics is a part of the supply chain including planning, implementing, controlling effectively, circulating effectively and storing goods and services and related information from basic point of supply to the place of consumption efficiently and effectively to meet the needs of customers. The term "logistics" is attracting the attention of 
enterprises and large corporations in the world, in Vietnam, the concept of logistics has been mentioned in the Trade Act of 2005. Article 233 of the Trade Act defines as follows: Logistics is a commercial activity, in which traders carry out one or more tasks including receiving, shipping, storing, implementing customs formalities and other papers, offering customers professional advice, packaging, coding, delivering or other services related to the goods as ag reed with the customer for remuneration. As defined above, logistics is similar to delivering and receiving that business people provide one of the services such as receiving, shipping, following the procedures..., which is considered as logistics supplier. Accordingly, logistics has similar elements with transportation, logistics providers are quite similar with MTO - Multimodal Transport Operator. However, the logistics here must be understood as a continuous service of many services, these services take place from pre-production until the goods are bought by the final consumers. Accordingly, the logistics associates with stages of importing raw materials and fuel for production, producing goods and put into circulation and distribution channels.

With the above characteristics, logistics depends on: 1) Infrastructure, 2) Legal framework (policies and legislation), 3) Reduction of Logistics cost. Logistics affecting the competitiveness of the businesses has been studied by Le Thi Minh Thao, 2008; Thai Tuan, Le Thi Minh Tam, Thai Thi Tu Phuong, 2014; Pham Thanh Binh, 2009; Bui Duy Linh, 2018. On that basis, Hypothesis $\mathrm{H} 1$ is proposed as follows: logistics has positive (+) effect on the competitiveness of enterprises.

\section{Marketing capacity}

Marketing capacity of the enterprise is the ability to capture market demand, plan marketing strategies and implement mixed marketing programs (4P), to promote and develop the brand name. Marketing capacity impacts directly on production and consumption of products, meets the needs of customers, increases profit, market share, enhance the position of the business.

Marketing capacity is also shown in the survey of market demand in order to select the suitable target market, build product strategies, assess products and develop distribution channels. Those activities are vital for the businesses.

Currently, with information explosion about products, creating brand names for products and businesses is vital for enterprises. Besides, promotion policy, sales service and after-sales play an important role in attracting and building a group of potential and traditional customers. In addition, the Marketing capacity is represented by closely monitoring the fluctuations of the market and responding to the market changes including:

(1) Meeting the needs of customers (Homburg et al., 2007) ;

(2) Adapting to the business environment (Srivatastava et al., (2001) Zarha et al. (1999);

(3) The quality of relationships with partners, suppliers, distributors, the authorities (Krasniko \& Jayachandran, 2008; Nguyen et al., 2004; Srivatastava et al., 2001).

From these marketing capacity variables (1), (2), (3) in this study, the author will add 3 variables; Meeting customer needs; adapting business environment; quality of relationship. Marketing capacity affecting the competitiveness of the businesses has been studied by Sivastava. R. K, Fahey. L, Christensen.HK, 2001; Chang et al (2007); Homburg et al (2007); Lee and King (2009); Zarha et al. (1999); Nguyen Cao Tri (2011); Tran The Hoang (2011); Tran Bao An et al (2012); Tran Huu Ai (2013); Day, (1994); Vorhies \& Harker, (2000); Srivatastava et al., (2001); Homburg et al., (2007); Kotler \& Armstrong (2012); Krasniko \& Jayachandran, 2008; Nguyen et al., 2004; Srivastava et al., 2001. On that basis, Hypothesis $\mathrm{H} 2$ is proposed as follows: marketing capacity has positive (+) effect on the competitiveness of enterprises.

\section{Administration capacity}

Administration capacity is the ability to organize, manage and operate business. It determines the existence and development of the business as well as the competitiveness of enterprises. The level of organization and management is reflected in the following aspects:

- The level of managerial staff

It is expressed through education level, specialized knowledge related to business activities of enterprises (from legislation, market, sector,... to social knowledge, humanities).

- The level of organization and management

It is shown in organizing, arranging management system and distributing the functions and tasks of the professional divisions. Building orderly and highly efficient management system is very important to help businesses make decisions quickly and accurately as well as reduce the cost of business management. Therefore, the competitiveness of enterprises is enhanced.

- Planning Capacity

It is significant in improving the operational efficiency of the business, has a large impact on the 
competitiveness of enterprises. According to Michael Porter, administration capacity is also reflected through the replacement speed of human resources during the changes.

Administration capacity affecting the competitiveness of the businesses has been studied by Porter, 1996; Bartlett A\& S Ghoshan, 1989; Nguyen Huu Thang, 2008; Tran Huu Ai, 2013; Lee and King (2009); Tsai, Song and Wong (2009); Mechinda et al. (2010); Nguyen Cao Tri (2011). On that basis, Hypothesis H3 is proposed as follows: administration capacity has positive (+) effect on the competitiveness of enterprises.

\section{Capacity of price}

The price of a product is constituted by the relative total costs plus expenses with the other units. The lower cost per unit of product the enterprises have, the more advantages they have than other businesses with higher cost. In "Competitive strategy according to Michael Porter Theory," Dr. Duong Ngoc Dung (2006) stated that to have the lowest cost, it is urgent to build infrastructure, equip with technology on a large scale to reduce costs as well as increase cost control, especially the costs which are not directly related to production. Low cost will be an effective protection in rivalry with other competitors because the lower cost means that companies can still gain profit although during the competition, the competitors have taken away their portion of profits. Capacity of competitive price affecting the competitiveness of the businesses has been studied by Dwyer, Forsyth and Rao (2000); Qu, H., Xu, and Tan (2002); Dwyer and Kim (2003); Mattila and O'Neil (2003); Lockyer (2005); Craigwell (2007). On that basis, Hypothesis $\mathrm{H} 4$ is proposed as follows: capacity of competitive price has positive (+) effect on the competitiveness of enterprises.

\section{Financial Capacity}

Finance is the first condition for production and business activities of enterprises. Finance establishes and operates businesses. Financial capacity of strong enterprises is shown in capital base, the ability to mobilize and use the capital, and the capacity of financial management. In Michael Porter's viewpoint, financial capacity is demonstrated in the capacity of financial management (mobilizing, managing, using capital efficiently, speeding up capital turnover). Mobilizing capital in time will meet the needs of purchasing machinery, equipment, raw materials, hiring workers, innovating technology and production lines, developing market... To improve the financial capacity, businesses need to consolidate and develop the capital, increase available capital, expand the loan, use effectively. Financial capacity affecting the competitiveness of the businesses has been studied by Lamarque, 2005; Kouser.R, Mehvish.H, Azeem.M, 2011; Feurer.R; Chaharbaghi, 1994; Nguyen Minh Tuan, 2010; Lamarque. E, 2005; Tran The Hoang, 2011; Tran Huu Ai, 2013; Chinn.M.D \& Ito.H, 2008; Tran Suu, 2006; Vu Trong Lam, 2006; Doz \& Prahalad, 1987; Nguyen Vinh Thanh, 2005. On that basis, Hypothesis H5 is proposed as follows: financial capacity has positive (+) effect on the competitiveness of enterprises.

\section{Capacity of brand name}

Brand name is the customers' trust, emotion and preference towards businesses and their products. Strong brands are capable to attract a large number of customers without high costs for advertisement. Currently, brand name has greatly affected on business results. Brand name has increasing density in the total assets of the business (the average value of a brand name accouning for about $1 / 3$ of the total assets of the enterprise, with service firms, brand name assets accounting for $50 \%$ of total assets)e. Brand names affect the ability to identify products, to persuade the customers to buy a product and the customer loyalty. A strong brand name is a major asset to be competitive. Capacity of competitive brand name affecting the competitiveness of the businesses has been studied by Keller (1993); Dwyer and Kim, 2003; Bui Xuan Phong, 2007; Konecnik, 2006; Berry, Zeithaml and Parasuraman, 1990; Tran Huu Ai, 2014; Tran The Hoang, 2011. On that basis, Hypothesis H6 is proposed as follows:capacity of competitive brand name has positive (+) effect on the competitiveness of enterprises.

\section{Capacity of Products}

A product is competitive when it satisfies the needs of customers in terms of quality, price, features, style, originality and superiority compared to the same products. Product capability associates with the benefits that the products bring to the customers and ensures the providing time. Quality of product or service is often measured by customer satisfaction and market share of a particular product in the market. Product competitiveness shows the advantages of the product compared to competitors, the evaluation criteria. Competitiveness of products includes the basic criteria and specific targets. The basic criteria include cost price and the price of the product, product quality, distribution systems and business reputation. Business reputation indicator affects the competitiveness of products, which shows that business competitiveness has fundamental and 
long-term influence on competitiveness of products. The specific criteria assessing the competitiveness of products include the quantitative and qualitative indicators.

\section{Quatitative indicators include basic targets:}

The market share of products in the market each year compared to the competitors', it is possible to calculate the market share when comparing with the entire market, with the market segment that enterprises choose to compare with the most competitive rival:

1. The levels of production, sales of that item each year compared to the competitors';

2 . The difference in price of goods compared with competitors'.

\section{Qualitative indicators include basic targets:}

1. The difference in the quality of products compared to competitors';

2. The level of attractiveness of the product design and style compared to competitors';

3. The impression of visual trademark of the manufacturer compared with the same type of merchandise of the competitors.

From these targets and concepts, the author has done statistics. Competitiveness of products has been studied by: Alan L.Porter, J.David Roessner, Nils Newman, Xiao Yin Zin (2000); Oh, 1999; Dube. Enz, Renagham \& Siguaw, 1999; Lewis \& Booms, 1983; Berry, Zeithaml \& Parasuraman, 1990. Experts' opinions in aquatic field in An Giang province were synthesized. So, the competitiveness of products has been studied quite a lot in this field and industry, but in the sector of aquatic export, there has been no $s$ tudies on the competitiveness of catfish products in An Giang Province. Therefore, the competitiveness of products I propose here is completely new and does not overlap with the previous studies. On that basis, Hypothesis $\mathrm{H7}$ is proposed as follows: competitiveness of products has positive (+) effect on the competitiveness of enterprises.

\section{Capacity of Human Resources}

A production process always needs four elements (4M). Among these four factors human (Human resources) plays a decisive role. Human resources are the most volatile and decide business production efficiency. Workforce uses production materials and equipment to produce the goods and services, participates in technical and production processes improvements. The level of labor greatly influences the quality and sophistication of the product, greatly affects the productivity and the cost of the business. This factor directly affects the competitiveness of enterprises. To enhance competitiveness, enterprises themselves should focus on ensuring the quality and quantity of labor, improving the skills of workers, encouraging employees to participate in the management process and technical improvement. Human resources have been studied by Porter (1980); Bueno; Craigwell (2007); Lee and King (2009); Tsai, Song and Wong (2009); Wayne (2010); Ivanovic, Mikinac and Perman (2011); Tran The Hoang (2011); Tran Huu Ai (2014); Nguyen Thanh Long (2016); Nguyen Van Dat (2016); Vu Duong Hoa (2017). On that basis, Hypothesis H8 is proposed as follows: human resources have positive (+) effect on the competitiveness of enterprises.

\section{Capacity of Developing Business Relations}

Operation of enterprises is always moderated and managed by the government and other concerned agencies. The enterprises which have good relations with the government will be more favorable for production as well as for the support from the development programs, especially in projects with appointed contractors, preferential loans (such as stimulus capital, capital of offshore fishing program in the aquatic sector...). Businesses which are unpopular with the governments will often confront inspections (about safety, fire prevention, environment,...). Therefore, the capacity of the business relationship is also considered as a competitive advantage. Capacity of developing business relations has been studied by Tran The Hoang, 2011; Tran Huu Ai, 2014. On that basis, Hypothesis H9 is proposed as follows: capacity of developing business relations has positive (+) effect on the competitiveness of enterprises.

\section{Capacity of Production Technology}

When the technical science has developed dramatically, equipping modern machines, applying modern technology in production greatly affects the competitiveness of enterprises. Appropriate technology helps the enterprises shorten production time, increase employees' productivity, reduce fuel consumption, increase productivity, lower product cost, improve product quality. Technology also affects the organization of production, the level of business automation. Moreover, the production technology which is environmentally friendly is a trend and creates a competitive advantage for businesses. Capacity of production technology has been studied by Nguyen Minh Tuan, 2010; Tran Ngoc Ca, 2011; ArThur A.Thompson; A J Strickland \& John Gamble, 2008. (Lospez. J \& Garcia. R, 2005; Corbett C \&L Wassennhove, 1983); Tran The Hoang, 2011; Tran Huu Ai, 2014; Nguyen Van Dat, 2016. On that 
basis, Hypothesis $\mathrm{H10}$ is proposed as follows: capacity of production technology has positive (+) effect on the competitiveness of enterprises.

\section{Research Methodology}

\section{Phase 1: Theoretical research}

From the research objectives, the author researched documents and related studies, made outline to interview experts, discussed in groups to establish models of theoretical research and designed questionnaires for preliminary investigation.

\section{Phase 2: Official research}

After the Pearson correlation analysis and multivariate regression analysis, the author conducted formal quantitative analysis with 10 elements: Administration, Finance, Technology, Price, Marketing, Human Resources, Brand name, Capacity of developing business relations, Products, Logistics. ( $\mathrm{N}=500$ questionnaires), through testing the reliability of the scale with Cronbach's alpha coefficient, analyzing exploratory factors EFA, analyzing confirmatory factor CFA, structural equation model SEM in order to verify strong or weak impact on the enterprise's competitiveness.

\section{Research Findings}

Testing scales of Human resources, Brand name, Technology, Marketing, Price, Product, Development of business relations, Administration, Finance, Cronbach's Alpha $\alpha$ of competitiveness fluctuated $\quad(0.802-0.938)>0.6$ which achieved reliability.
Table 1. Results of Cronbach's Alpha coefficient inspection of scales

\begin{tabular}{|l|c|c|l|}
\hline \multicolumn{1}{|c|}{ Scale } & $\begin{array}{c}\text { Number } \\
\text { of } \\
\text { observed } \\
\text { variables }\end{array}$ & $\begin{array}{c}\text { Cronbach } \\
\text { 's Alpha }\end{array}$ & \multicolumn{1}{|c|}{ Note } \\
\hline Fin & 5 & 0.931 & \\
\hline Product & 5 & 0.914 & \\
\hline Tech & 4 & 0.870 & \\
\hline Admin & 6 & 0.936 & \\
\hline Relationship & 4 & 0.938 & \\
\hline Price & 5 & 0.924 & \\
\hline HR & 5 & 0.881 & \\
\hline Brand name & 5 & 0.920 & \\
\hline $\begin{array}{l}\text { MKtg- } \\
\text { Satisfying }\end{array}$ & 2 & 0.813 & $\begin{array}{l}\text { Excluding MR2 } \\
\text { variable because } \\
\text { coefficient Corrected } \\
\text { Item-Total } \\
\text { Correlation=0.152 }<0.3\end{array}$ \\
\hline $\begin{array}{l}\text { MKtg- } \\
\text { adapting }\end{array}$ & 3 & 0.877 & \\
\hline MKtg- \\
relation
\end{tabular}

\section{Analyzing EFA}

Results showed that 10 factors were extracted from 57 variables measuring the properties of the elements in the inner environment and the environment of businesses. These ten factors had total variance extracted of $70.666 \%>50 \%$, the scale is accepted. KMO coefficient $=0.907>0.5$ is in the range of $0.5 \leq 1 \leq \mathrm{KMO}$, factor analysis is appropriate. All Factor loading values of each group are greater than 0.50 so they are satisfactory, so the scales of EFA factor analysis are valuable.

Table 2. Results analysis of EFA

Pattern Matrix ${ }^{\mathrm{a}}$

\begin{tabular}{|l|c|c|c|c|c|c|c|c|c|c|c|}
\hline & \multicolumn{10}{|c|}{ Factor } \\
\cline { 2 - 10 } & 1 & 2 & 3 & 4 & 5 & 6 & 7 & 8 & 9 & 10 & 11 \\
\hline LOG- Cost & .912 & & & & & & & & & & \\
\hline LOG- Infra & .891 & & & & & & & & & & \\
\hline LOG- Cost & .868 & & & & & & & & & & \\
\hline LOG- Leg & .842 & & & & & & & & & & \\
\hline LOG- Infra & .806 & & & & & & & & & & \\
\hline LOG- Leg & .724 & & & & & & & & & & \\
\hline
\end{tabular}




\begin{tabular}{|c|c|c|c|c|c|c|c|c|c|c|c|}
\hline LOG- Infra & .704 & & & & & & & & & & \\
\hline MKtg- relation & & 890 & & & & & & & & & \\
\hline MKtg-Adapting & & .879 & & & & & & & & & \\
\hline MKtg-Satisfying & & .863 & & & & & & & & & \\
\hline MKtg-relation & & 857 & & & & & & & & & \\
\hline MKtg- Adapting & & .834 & & & & & & & & & \\
\hline MKtg-Adapting & & 807 & & & & & & & & & \\
\hline MKtg-Satisfying & & .770 & & & & & & & & & \\
\hline Admin 4 & & & .899 & & & & & & & & \\
\hline Admin 6 & & & .894 & & & & & & & & \\
\hline Admin 2 & & & .889 & & & & & & & & \\
\hline Admin 3 & & & .857 & & & & & & & & \\
\hline Admin 1 & & & .789 & & & & & & & & \\
\hline Admin 5 & & & .743 & & & & & & & & \\
\hline Price 4 & & & & .906 & & & & & & & \\
\hline Price 5 & & & & 901 & & & & & & & \\
\hline Price 2 & & & & 836 & & & & & & & \\
\hline Price 1 & & & & .811 & & & & & & & \\
\hline Price 3 & & & & .752 & & & & & & & \\
\hline Fin 5 & & & & & .935 & & & & & & \\
\hline Fin 4 & & & & & .917 & & & & & & \\
\hline Fin 3 & & & & & .849 & & & & & & \\
\hline Fin 1 & & & & & .813 & & & & & & \\
\hline$\overline{\text { Fin } 2}$ & & & & & .737 & & & & & & \\
\hline Brand name 4 & & & & & & .900 & & & & & \\
\hline Brand name 2 & & & & & & .891 & & & & & \\
\hline Brand name 3 & & & & & & .861 & & & & & \\
\hline Brand name 5 & & & & & & .778 & & & & & \\
\hline Brand name 1 & & & & & & .758 & & & & & \\
\hline Product 4 & & & & & & & .892 & & & & \\
\hline Product 2 & & & & & & & .892 & & & & \\
\hline Product 3 & & & & & & & .840 & & & & \\
\hline Product 5 & & & & & & & .763 & & & & \\
\hline Product 1 & & & & & & & .752 & & & & \\
\hline HR 5 & & & & & & & & .840 & & & \\
\hline HR 4 & & & & & & & & .811 & & & \\
\hline $\begin{array}{l}\text { HR } 1 \\
\end{array}$ & & & & & & & & .744 & & & \\
\hline HR 3 & & & & & & & & .741 & & & \\
\hline HR 2 & & & & & & & & .713 & & & \\
\hline Relation 4 & & & & & & & & & .945 & & \\
\hline Relation 1 & & & & & & & & & .873 & & \\
\hline Relation 3 & & & & & & & & & .835 & & \\
\hline Relation 2 & & & & & & & & & .830 & & \\
\hline Tech 4 & & & & & & & & & & .875 & \\
\hline Tech 2 & & & & & & & & & & .841 & \\
\hline Tech 1 & & & & & & & & & & .676 & \\
\hline Tech 3 & & & & & & & & & & .552 & \\
\hline & & & & & & & & & & & .913 \\
\hline Competitiveness 3 & & & & & & & & & & & .732 \\
\hline & & & & & & & & & & & .700 \\
\hline
\end{tabular}

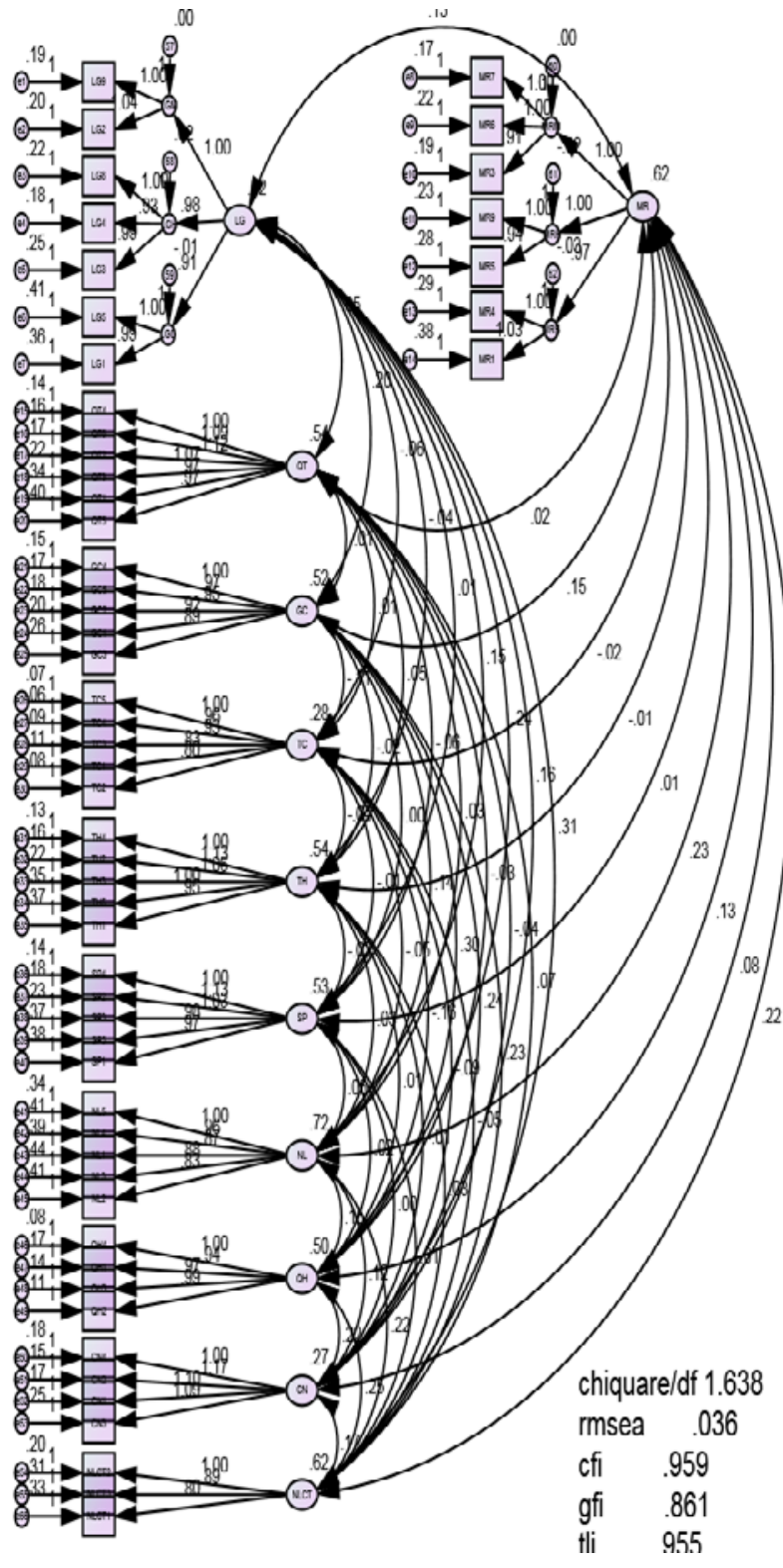

Fig.1. Critical CFA Results

The result of the final CFA measurement model shows that the model is consistent with the data (specified in Figure 1), Chi-squared (Chi-square = 2331.316), degrees of freedom $(\mathrm{DF}=1423)$, the value of $\mathrm{P}=0.000 ; \mathrm{Cmin} / \mathrm{df}$ (Chi-square / $\mathrm{DF}=$ $1,638<3$ ). Other measuring indicators are also satisfactory $(\mathrm{GFI}=.861 ; \mathrm{TLI}=.955 ; \mathrm{CFI}=.959$ are greater than 0.8 ; RMSEA $=0036<0.8$ ). 
Table 3. Synthetic reliability $(\mathrm{Pc})$ và variance extracted (Pvc)

\begin{tabular}{|l|c|c|c|}
\hline \multicolumn{1}{|c|}{ Factor } & Pc & Pvc & Note \\
\hline Administration & 0.935 & 0.783 & \\
\hline Finance & 0.933 & 0.735 & \\
\hline Technology & 0.872 & 0.631 & \\
\hline Price & 0.925 & 0.712 & \\
\hline Marketing- Satisfying & 0.808 & 0.678 & \\
\hline Marketing- Adapting & 0.874 & 0.698 & \\
\hline Marketing- Relation & 0.867 & 0.766 & \\
\hline Human resources & 0.862 & 0.598 & \\
\hline Brand name & 0.922 & 0.704 & \\
\hline Relation & 0.939 & 0.794 & \\
\hline Product & 0.917 & 0.689 & \\
\hline Logistic- Infrastructure & 0.865 & 0.682 & \\
\hline Logistics- Legislation & 0.783 & 0.783 & \\
\hline Logistics- Cost & 0.798 & 0.798 & \\
\hline Competitiveness & 0.841 & 0.640 & \\
\hline
\end{tabular}

Synthetic Pc reliability of all scale varied [0.7830939]>0.6. Pvc variance extracted of all scales ranged between [0598-0798] $>0.5$, the scale achieved reliability. Based on the GFI, CFI, TLI, RMSEA, Chi-square/degrees of freedom indicators, measurement results show that all scales are unidirectional, ensure the value of convergence, the reliability and value distinction. Research model is consistent with the data.

\section{Verifying the research model by structural equation model SEM}

SEM inspection based on CFA test results shows that the scale of research models have reached the consistent level with the data through the indicator of value convergence, value distinction, synthetic reliability and variance extracted. Therefore, the hypothesis of the official research model has no changes or adjustments. Verifying hypothesis and research models by SEM model has more advantages than traditional methods such as multivariate regression because proposed error can be caculated. In addition, that allows combining the implicit concepts with the theoretical model simultaneously (Hulland et al., 1996). Maximum Likelihood is used to estimate the parameters of the research model if the data have a standardized distribution. AMOS software is applied to analyze the structural equation model SEM to verify the research model including the concepts of the research model and official survey with 57 observed variables, and one general concept of the aquatic exporters' competitiveness in An Giang Province with three variations observed. The estimation results (standardized) of the research model showed that the model was fit to the data (specified in Figure1), Chi-squared (Chi-square $=$ 2331.316) with degrees of freedom ( $\mathrm{DF}=1423), \mathrm{P}$ $=0.000$ value; $\mathrm{Cmin} / \mathrm{df}$ (Chi-square $/ \mathrm{DF}=1,638$ $<3)$. Other measuring indicators are also satisfactory $(\mathrm{GFI}=.861 ; \mathrm{TLI}=.955 ; \mathrm{CFI}=.959$ are greater than 0.8 ; RMSEA $=0036<0.8$ ).

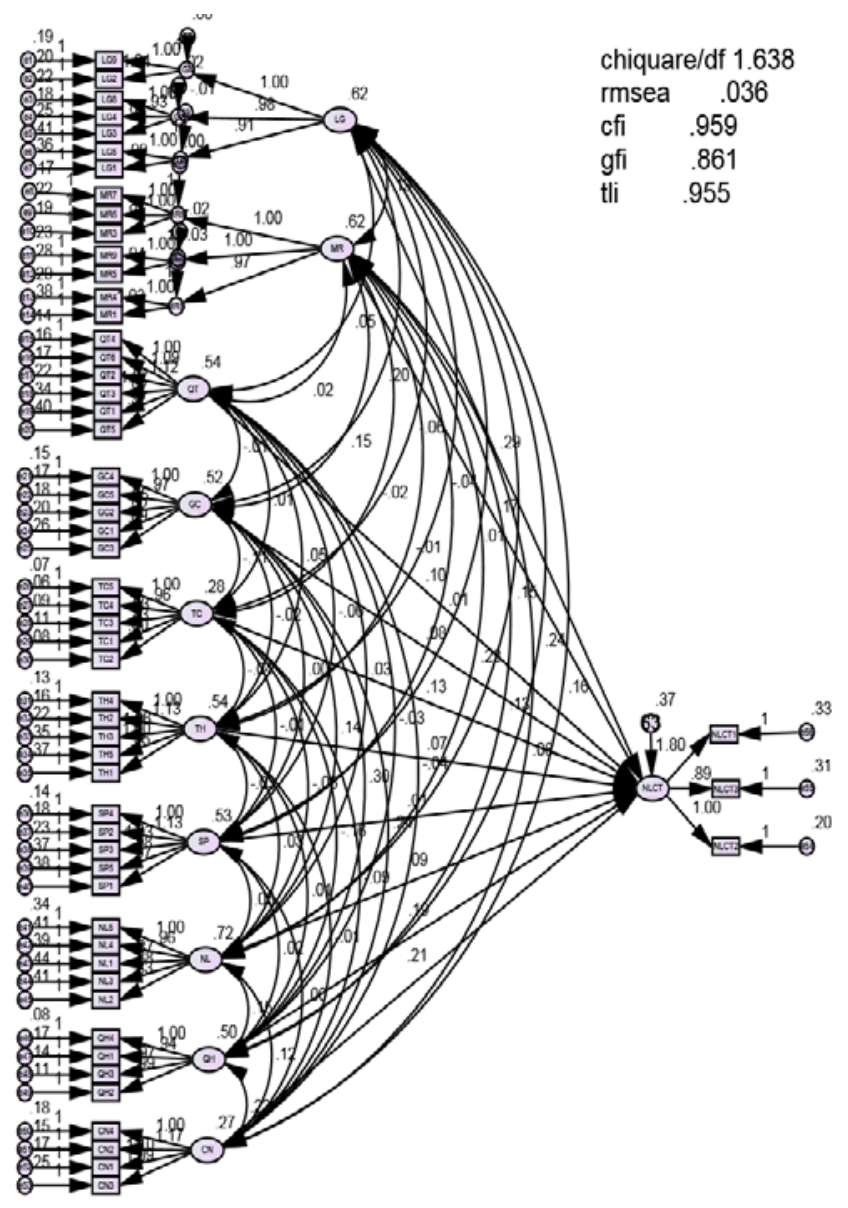

F1g.L. Structural equation model SEIV

Table 4. The result of inspection of hypotheses on the relationship between factors

\begin{tabular}{|c|c|c|c|c|c|c|}
\hline & & & $\begin{array}{c}\text { Estima } \\
\text { te }\end{array}$ & S.E. & C.R. & $\mathbf{P}$ \\
\hline LOG-Infra & $\begin{array}{c}<-- \\
-\end{array}$ & LG & 1 & & & \\
\hline LOG- Leg & $\begin{array}{c}<- \\
- \\
\end{array}$ & LG & 0.98 & 0.04 & $\begin{array}{c}24.6 \\
85 \\
\end{array}$ & $* * *$ \\
\hline LOG- Cost & $\begin{array}{l}<- \\
-\end{array}$ & LG & 0.905 & $\begin{array}{c}0.04 \\
5\end{array}$ & $\begin{array}{c}20.3 \\
07\end{array}$ & $* * *$ \\
\hline $\begin{array}{l}\text { MKtg- } \\
\text { Satisfying } \\
\end{array}$ & $\begin{array}{c}<-- \\
- \\
\end{array}$ & MKtg & 1 & & & \\
\hline $\begin{array}{l}\text { MKtg- } \\
\text { Adapting }\end{array}$ & $\begin{array}{c}<-- \\
- \\
\end{array}$ & MKtg & 1.003 & $\begin{array}{c}0.03 \\
7 \\
\end{array}$ & $\begin{array}{c}26.9 \\
58 \\
\end{array}$ & $* * *$ \\
\hline $\begin{array}{l}\text { MKtg- } \\
\text { relation }\end{array}$ & $\begin{array}{c}<- \\
- \\
\end{array}$ & MKtg & 0.968 & $\begin{array}{c}0.03 \\
9 \\
\end{array}$ & $\begin{array}{c}24.9 \\
44 \\
\end{array}$ & $* * *$ \\
\hline $\begin{array}{l}\text { Competitive } \\
\text { ness }\end{array}$ & $\begin{array}{c}<-- \\
-\end{array}$ & LOG & 0.295 & $\begin{array}{c}0.04 \\
9\end{array}$ & 5.98 & $* * *$ \\
\hline $\begin{array}{l}\text { Competitive } \\
\text { ness }\end{array}$ & $\begin{array}{c}<-- \\
-\end{array}$ & MKtg & 0.174 & $\begin{array}{c}0.04 \\
6\end{array}$ & $\begin{array}{c}3.81 \\
6\end{array}$ & $* * *$ \\
\hline
\end{tabular}




\begin{tabular}{|c|c|c|c|c|c|c|}
\hline $\begin{array}{l}\text { Competitive } \\
\text { ness }\end{array}$ & $\begin{array}{l}<- \\
- \\
\end{array}$ & $\begin{array}{c}\text { Admi } \\
\mathrm{n}\end{array}$ & 0.103 & $\begin{array}{c}0.04 \\
5\end{array}$ & $\begin{array}{c}2.28 \\
1 \\
\end{array}$ & $\begin{array}{c}0.02 \\
3 \\
\end{array}$ \\
\hline $\begin{array}{l}\text { Competitive } \\
\text { ness }\end{array}$ & $\begin{array}{c}<- \\
-\end{array}$ & Price & 0.077 & $\begin{array}{c}0.06 \\
8\end{array}$ & $\begin{array}{c}1.13 \\
5\end{array}$ & $\begin{array}{c}0.25 \\
6\end{array}$ \\
\hline $\begin{array}{l}\text { Competitive } \\
\text { ness }\end{array}$ & $\begin{array}{c}<- \\
-\end{array}$ & Fin & 0.135 & $\begin{array}{c}0.06 \\
9\end{array}$ & $\begin{array}{c}1.95 \\
9\end{array}$ & 0.05 \\
\hline $\begin{array}{l}\text { Competitive } \\
\text { ness }\end{array}$ & $\begin{array}{c}<- \\
-\end{array}$ & $\begin{array}{l}\text { Brand } \\
\text { name }\end{array}$ & 0.071 & $\begin{array}{c}0.04 \\
5\end{array}$ & $\begin{array}{c}1.57 \\
4\end{array}$ & $\begin{array}{c}0.11 \\
6 \\
\end{array}$ \\
\hline $\begin{array}{l}\text { Competitive } \\
\text { ness }\end{array}$ & $\begin{array}{l}<- \\
- \\
\end{array}$ & $\begin{array}{c}\text { Produ } \\
\text { ct }\end{array}$ & 0.013 & $\begin{array}{c}0.04 \\
5\end{array}$ & $\begin{array}{c}0.28 \\
6 \\
\end{array}$ & $\begin{array}{c}0.77 \\
5 \\
\end{array}$ \\
\hline $\begin{array}{l}\text { Competitive } \\
\text { ness }\end{array}$ & $\begin{array}{c}<- \\
- \\
\end{array}$ & HR & 0.094 & $\begin{array}{c}0.04 \\
4\end{array}$ & $\begin{array}{c}2.13 \\
8 \\
\end{array}$ & $\begin{array}{c}0.03 \\
3\end{array}$ \\
\hline $\begin{array}{l}\text { Competitive } \\
\text { ness }\end{array}$ & $\begin{array}{c}<- \\
-\end{array}$ & $\begin{array}{c}\text { Relati } \\
\text { on }\end{array}$ & 0.193 & $\begin{array}{c}0.06 \\
9\end{array}$ & $\begin{array}{c}2.80 \\
5\end{array}$ & $\begin{array}{c}0.00 \\
5\end{array}$ \\
\hline $\begin{array}{l}\text { Competitive } \\
\text { ness }\end{array}$ & $\begin{array}{c}<- \\
-\end{array}$ & Tech & 0.209 & $\begin{array}{c}0.10 \\
4\end{array}$ & $\begin{array}{c}2.00 \\
4\end{array}$ & $\begin{array}{c}0.04 \\
5\end{array}$ \\
\hline
\end{tabular}

The estimation results (standardized) of the main parameters which are presented in Table 4 show that these causal relationships are statistically significant $(\mathrm{p}<5 \%)$. (Except Marketing-quality relationship does not satisfy the conditions). Based on the results of estimating standadized relations of the model, we conclude that the concepts of the research model gained the value of theoretical linking.

\section{Conclusion}

From the research results, we see the proposed additional factors in the model impact on the aquatic exporters' competitiveness. Testing the reliability of the Human resources, Brand name, Technology, Marketing, Price, Product, Development of business relations, Administration, Finance, competitiveness scales, all with Cronbach's Alpha $\alpha$ which varied in the range of (0.802-0.938) $>0.6$ achieved reliability.

The EFA results showed that 10 factors which were extracted from the 56 variables measuring factors affecting the competitiveness of enterprises had total variance extracted of $70.666 \%>50 \%$, the scale is accepted. KMO coefficient $=0907>0.5$ was in the range of $0.5 \leq 1 \leq \mathrm{KMO}$, factor analysis is appropriate. All Factor loading values of each group are greater than 0.50 , so they are satisfactory, the scales of EFA are valuable.

Factor analysis confirmed the scale of finance, product, technology, administration, relationships, price, human resources, brand name, marketing, logistics. Standardized regression of the observed variables in this scale has reached significance $(\mathrm{p}=$ 0.000 should have statistical significance) and has great value varying from 0.779 to $0.122>0.5$. This result shows that the variables of this component are unidirectional and achieve convergence value. Synthetic Pc reliability of all scales varies in the range of [0.783-0939] $>0.6$. Pvc variance extracted of all scales varies in the range of [0598-0798]>0.5, the scale achieved reliability.

The results of estimating (standardized) research model showed that the model is consistent with the chi-squared data (Chi-square $=2331.316)$ with degrees of freedom $(\mathrm{DF}=1423)$, the value of $\mathrm{P}=$ 0.000; $\mathrm{Cmin} / \mathrm{df}($ Chi-square/DF $=1,638<3)$. Other measuring indicators are also satisfactory $(\mathrm{GFI}=.861 ; \mathrm{TLI}=.955 ; \mathrm{CFI}=.959$ are greater than $0.8 ; \mathrm{RMSEA}=0036<0.8$ ). The estimation results (standardized) of the main parameters which are presented in Table 4 show that these causal relationships are statistically significant $(\mathrm{p}<5 \%)$. (Except Marketing-quality relationship does not satisfy the conditions). Based on the results of estimating standadized relations of the model, we can conclude that the concepts of the research model gained the value of theoretical linking.

\section{Recommendations}

The tests proved that the proposition of additional factors into the model is appropriate. These factors greatly influence the competitiveness of enterprises, so the author recommends solutions according to each factor.

\section{Finance}

Finance in the aquatic export business is an important factor to ensure the smooth and on schedule operation of the business in order to implement the goals of the enterprises. Enhancing the ability of mobilizing capital since the enterprises cannot depend on $g$ overnment assistance. Saving through carefully review the portfolio to remove the high-risk projects. Fully utilizing opportunities about policies, first of all is the government's stimulus package to solve the problem of capital, increase the competitiveness in export.

\section{Products}

For aquatic export businesses, the product quality factor is vital because their customers are the advanced countries. Therefore, product quality, food safety are highly required. Increasing the production of clean products with no antibiotic residues, no pr eservatives, products with added value meet the demanding markets such as USA, EU, Japan ...

\section{Technology}

It is vital to invest in modern technological lines to shorten the production process, save time, liberate labor. The aquatic processing enterprises should adopt modern technology, implementate the process strictly from the stage of receiving material 
to the preservation of finished products before selling in the market. Applying ISO process is a critical requirement.

\section{Business Administration}

Forming management staff with high qualifications based on good recruitment and regular training. Proposing strategies to allocate resource associated with the strategic objectives. Training skillful staff for quality inspection and food hygiene. It is extremely important to equip the staff with foreign languages, especially English in improving the busisness administration.

\section{Business relation development}

Participating in international aquatic fairs to promote the development of business relations. Active participation in aquatic fairs, exhibitions is always the most effective way to introduce and promote their products, seek markets and develop business partners. Take the participation of Vietnam in Boston international aquatic fair as an example which needs to be replicated in the future. This prestigious international exhibition with the scale of nearly 1,200 booths attracted the participation of representatives of companies, large corporations, associations in the field of food processing, preserving and packaging and distributing from 40 countries around the world.

\section{Price}

Price competition is very fierce. This is a common type of competition on aquatic export market. The aquatic enterprises in Vietnam are known as providers of aquatic product with reasonable prices, fairly good and average quality. By strategy of reasonable price, Vietnam has exported to many large markets such as: North America, EU, Japan. However, cheap price has gradually lost its advantage and aquatic resources are dwindling fast; aquaculture water sources have been seriously polluted; along with antibiotic residues in meat and fish; preservatives infection; natural disasters, continuous drought; In this situation, the author suggests:

1) First, for some potential markets which requires moderate quality (such as Middle East, South America, China, Brazil, Mexico), enterprises can continue to maintain low price strategy to increase competition for some time.

2) Second, the demanding high-end markets such as Japan, the EU, North America, businesses use a high price strategy (approaching the rivals' prices) with equivalent high-quality products. Businesses can promote this good strategy by modernizing production technology line and controlling strictly material resources and ensuring requirements on food safety.
3) Third, enterprises should strengthen mutual coordination for reference in price to avoid devaluating. VASEP must play a coordinating role for the common good in settling of internal disputes, setting the compromise to avoid unfair competition on the market of raw materials.

\section{Human resources}

Arranging existing workers in the enterprises reasonably. Discovering capable people to arrange them with suitable job in each stage, each step of the production process such as cleaning, fileting, packaging, ... etc. Adding qualified workforce and replacing workers who are incompetent, unqualified, violate law and morality. Diversifying skills and ensuring high adaptability of workers when there is a requirement of labor adjustments in internal businesses. This measure will help businesses adjust labor easily when there are fluctuations and reduce recruitment costs.

Regular trainings in enterprises are necessary for workers, employees to know how to manage the quality well in each stage of their work such as cleaning, fileting, packaging, labeling, storing, preserving well ... etc. Those ways are important measures to enhance the competitiveness of human resources.

\section{Marketing}

Enterprises should focus on trade promotion. First of all, focusing on advertising on newspapers, radio, television, social networking sites and other media for 3 goals consisting of offering, feeling and reminding for the customers. Besides, promotional activities promote the outstanding features of the product and the additional services. In addition to the mass media, businesses need to promote products through domestic and international aquatic fairs.

\section{Brand name}

Forming and developing innovative brand name based on the specific products of the enterprises, the development trend of the aquatic industry, the characteristics of the market, the business strategy of the businesses and emotions of the customers. At present, in An Giang many brand names are the names of the entrepreneurs which are long and hard to remember. Therefore, businesses here can hold competitions of designing logo, brand name, or consult experts for the best brand name.

\section{Logistics}

Infrastructure is a d ecisive factor in the development of aquatic exports. We need to synchronize traffic infrastructure, warehouse and information technology, gradually modernize technical infrastructure and services for the development of aquatic exports. In the future, we 
need to focus on $\mathrm{b}$ uilding and developing the appropriate ports because aquatic exports mainly transport by containers to meet the requirements of being fast, safe and effective. Therefore, it should focus on $b$ uilding the container terminal and transshipment port for domestic and regional container shipping to improve the efficiency of supply chains for import and export enterprises. Existing transport system in our country has many types of transport with quite favorable route. Besides that, the state needs to continue to research and open new transportation routes to meet the increasing demand for domestic and international cargo transportation.

\section{The limitations of study}

Although authors have tried, the study still has certain limitations. We did not combine Artificial Intelligence in the study. The research scope only focuses on A n Giang province so it is not very much strong. These are the directions for future research.

\section{References:}

[1] Aldington, Report from the Select Committee of the House of Lords on Overseas Trade, London: HMSO, 1985.

[2] Ali, B., Sopian, K., Chan, H. Y., Mat, S., \& Zaharim, A, Key success factors in implementing renewable energy programme in Malaysia. WSEAS Transactions on Environment and Development, 4(12), 2008, pp. 1141-1150.

[3] ArThur A.Thompson, Jr; A J.Strickland and John Gamble, Crafting and Excuting Strategy: The quest for competitive advantage:concepts and cases, New York: Mc Graw - Hill. 2008.

[4] Bach Thu Cuong, Discussion of Global Competition, Information, 2002.

[5] Babcock, B. A., Rural America and Modern Agriculture: What Kind of Future? Iowa Ag Review, 8(2), 2002.

[6] Barkema, A., Reaching Consumers in the Twenty First Century: The Short Way Around the Barn. American Journal of Agricultural Economics, 75(5), 1993.

[7] Bartlett A and S Ghoshal, Managing Across Borders. Harvard Business School Press, Boston, MA', 1989.

[8] Benedetto D.C.A \& Crawford C.M, New products management, Irwin/Mc Graw Hill, 2008.

[9] Bueno, A., Competitiveness in the tourist industry and the role of the Spanish public administration. Tourism, 47 (4), 1999, pp. 316-331.
[10] Berry, L, Zeithaml, V. A, \& Parasuraman, A., Five imperatives for improving service quality. Sloan Management Review, 31(4), 1990, pp. 29-38.

[11] Bui Duc Tuan, Improving the Competitiveness of the Aquatic Processing Industry in Vietnam, Economic Doctoral Dissertation, University of National Economics, 2010.

[12] Bui Xuan Phong, Business administration of Telecommunication in the Direction of Economic Integration, Post Office, Hanoi, 2006.

[13] Chang, Competitiveness and private sector development, 2007.

[14] Chinn. M.D, and Ito. H, New measures of financial openness. Journal of Comparative Policy Analysis, Vol. 10(4), 2008, pp. 309322.

[15] Corbett C and L Wassenhove, Trade offs ? What trade offs? competance and competitiveness in manufacturing. California management review, 35(4), 1983, pp. 107 122.

[16] Craigwell,R., Tourism Competitiveness in Small Island developing States. South Asia. Research Paper No. 2007/19.

[17] Day,G.S, The Capabilities of market- driven organizations. Journal of Marketing, 58, 1994, pp 37-52.

[18] Doz YL and CK Prahalad, The multinaional mission, New York: The free press, 1987.

[19] Dr.Oral Capps, Jr, FABA Managing Partner and Executive professor. Texas A\& $M$ University. Dr Gary W. William FABA team and professor Texas A\& M University, How Effectively does the Norwegian Seafood. Council promote Norwegian seafood exports? Journal of bussiness research case of seafood from Norway, 2017.

[20] Dube, L., Enz, C. A., Renaghan, L. M., \& Siguaw, J. A., American lodging excellence: The key to best practices in the U.S lodging industry, Washington DC: American Hotel Foundation. 1999.

[21] Dwyer, L., \& Kim, C., Destination competitiveness: Determinants and indicators by current issues. Current Issues in Tourism, 6(5), 2003, pp. 369-414.

[22] Dwyer, L., Forsyth, P., \& Rao, P, The price competitiveness of travel and tourism: A comparison of $19 \mathrm{de}$ stinations. Tourism Management, 21(1), 2000, pp 9-22.

[23] Feurer. R, Chaharbaghi, Defining competitiveness: A holistics approach. Management Desision, 32(2), 1994, pp. 49-60. 
[24] Galanis, A., \& Eliou, N, Evaluation of the pedestrian infrastructure using walkability indicators. WSEAS Transactions on Environment and Development, 7(12), 2011, pp. 385-394.

[25] Homburg, C., Grozanovic, M., \& Klarmann, M., Responsiveness to customers and competitor: The role of affective and cogtinive organizational systems. Journal of Marketing, 71, 2007, pp. 18-38.

[26] Ivanovic, S., Mikinac, K., \& Perman, L., CRM development in hospitality companies for the purpose of increasing the competitiveness in the tourist market. UTMS Journal of Economics, 2(1), 2011, pp. 59-68.

[27] Jayasekhar Somasekha ran, Harilar, k. N\& Parameswaran M, Research on: Responding to the Standard Regime. Analysis of Export Competitiveness of the Indian Fisheries Sector, 2012.

[28] Jean Louis MUCHIELLI, La compétitivité: définitions, indicateurrs et déterminantes, ACCOMEX, Paris, 2002.

[29] Keller, K.L., Conceptualizing, measuring, and managing customer-based brand equity. Journal of Marketing, vol. 57, 1993, pp. 1-22.

[30] Konecnik-Maja, Croatian-based brand equity for Slovenia as a tourism destination. Journal of Economic and Business Review for Central and South-Eastern Europe, vol. 8, no. 1, February, 2006.

[31] Kotler. P, \& Amstrong. G, Principle of Marketing $\left(14^{\text {th }}\right.$ ed), Pearson Prentice Hall, 2012.

[32] Kouser. R, Mehvish. H, Azeem. M. CAMEL, Analysis for islamic and conventional banks: Comparative study from Pakistan..Economics and Finance Review, 1(10), 2011, pp. 55-64.

[33] Kralj, D. A. V. O. R. I. N., \& Markic, M. I. R. K. O. Sustainable development strategy and product responsibility. WSEAS Transactions on Environment and Development, 4(2), 2008, pp. 109-118.

[34] Kulapasupongpan Kuldick, An economic analysis of the Thailand Tuna fish industry, $A$ thesis submitted to the Newcastle University for the degree of doctor of Philosophy, 2009.

[35] Lamarque.E, Indentifying key activities in banking firms: Acompetence based analysis. Advances In Applied Business Strategy, 7, 2005, pp. 29- 47.

[36] Le Thi Minh Thao, Enhancing the Competitiveness of Logistics Enterprises in the Integration Period into World Trade Organization (WTO), 2008.
[37] Lee, C.-F. \& King, B., A determination of destination competitiveness for Taiwan's hot springs tourism sector using the Delphi technique. Journal of Vacation Marketing, 15(3), 2009, pp. 243-257.

[38] Levins, R. A., A New Generation of Power. Choices, Second Quarter: 43-46, 2000.

[39] Lewis, R. C., \& Booms, B. H., The marketing aspects of service quality. In L. Berry, G. Shostack, \& G. Upah (Eds.), Emerging perspectives on services marketing. Chicago: American Marketing Association, 1983.

[40] Lockyer, T., The perceived importance of price as one hotel selection dimension. Tourism Management, 26(4), 2005, pp. 529537.

[41] Lopez. J, and Garcia. R, Technology and export behavior: a resourcebased view approach. International Business Review, Vol. 14( 5), 2005, pp. 539- 557.

[42] Mattila, A. S, \& O’Neill, J. W., Relationships between hotel room pricing, occupancy and guest satisfaction: A longitudinal case of midscale hotel in the United States. Journal of ospitality \& Tourism Research, 27(3), 2003, pp. 328-341.

[43] Micheal Porter, Competitive strategy, Young, Ho Chi Minh City, 1980.

[44] Mechinda, P. et al., The relative impact of competitiveness factor and destination equity on tourist's loyalty in Koh Chang, Thailand. International Business \& Economics Research Journal, October 2010, Vol 9, num ber 10, 2010, pp. 99-114.

[45] Nguyen Cao Tri, Enhancing the Competitiveness of the Tourism Enterprises in Ho Chi Minh City up to 2020. Economic Doctoral Dissertation, University of Economics Ho Chi Minh City, 2011.

[46] Nguyen Minh Tuan, Enhancing the Competitiveness of the State Enterprises in International Economic Integration, National University, Ho Chi Minh City, 2010.

[47] Nguyen,T,N,Q, Knowledge management Capapility and competitive advantage: an empirical study of Vietnam enterprises. Unpublished Doctor of Philosophy, Southern Cross, 2010.

[48] Nguyen Thanh Long, Studying the Factors Affecting the Tourism Enterprises' Competitiveness in Ben Tre. Economic Doctoral Dissertation, University of Economics Ho Chi Minh City, 2016.

[49] Nguyen Van Thuy, The Influence of the Competitiveness on the Business Results of 
Joint Stock Commercial Banks in Ho Chi Minh City, 2015.

[50] Nguyen Vinh Thanh, Enhancing the Competitiveness of Vietnamese Enterprises in the Current Period, 2005.

[51] Oh, H., Service quality, customer satisfaction, and customer value: A holistic perspective. International Journal of Hospitality Management, 18(1), 1999, pp. 67-82.

[52] Pavel Taraba, Project Management Methods in Conditions of Business Companies in the Czech Republic, International Journal of Circuits, Systems and Signal Processing, Vol.13, 2019, pp. 46-52.

[53] Pham Thanh Binh, Developing Logistics in the Formation of ASEAN Economic Community National Project, Economic and Political Institute of the World-Vietnam Academy of Social Sciences, 2009.

[54] Porter. M. E, What is strategy? Havard Business Review, November, 1996, pp. 61 78.

[55] Qu, H., Xu, P., \& Tan, A., A simultaneous equations model of the hotel room supply and demand in Hong Kong. International Journal of Hospitality Management, 196 21(4), 2002, pp. 455-462.

[56] Ramasamy, H, Productivity in the Age of Competitiveness: Focus on Manufacturing in Competitiveness, Asian Productivity Organization, APO Monograph Series 16, 1995.

[57] Sanchez, R., \& Heene, A, Strategic Learning and Knowledge management. West Sussex, England: John Wiley \& Sons Ltd, 1996.

[58] Sanchez, R., \& Heene, A, A Focused Issue on Building New Competences in Dynamic Environments, Emerald Group Publishing Limited, 2004.

[59] Schweikhardt, D. B., Reconsidering the Farm Problem under An Industrialization Agricultural Sector. Department of Agricultural Economics, Michigan State University, 2000, pp. 01-15.

[60] Sivastava. R. K, Fahey. L,Christensen. H. K, The resource based view and marketing:The role of market based assets in gaining competitive advantage. Journal of management, 27, 2001, pp. 777 -802.

[61] Thompson, Strickland \& Gamble, Studying an Enterprise's Components of Overall Competitiveness, 2007.

[62] Thai Anh Tuan, Thai Thi Tu Phuong, Le Thi Minh Tam, Enhancing the Competitiveness of the Logistics Industry in Vietnam, Economic and Forecast Journal, No. 11, 2014, pp. 3941.

[63] Tran Ngoc Ca, Enhancing the Competitiveness of Vietnamese Enterprises: The Technological Path. Journal of Economics and Development, 165, 2011, pp. 3-7.

[64] Tran Suu, Competitiveness of the Enterprises in Globalization, Labour, Hanoi, 2006.

[65] Tran The Hoang, Improving the Competitiveness of the Aquatic Export Enterprises in Vietnam up to 2020, Economic Doctoral Dissertation, University of Economics Ho Chi Minh City, 2011.

[66] Tran Van Dat, Studying the Factors Affecting the Coffee Enterprises' Competitiveness in Dak Lak Province, Economic Doctoral Dissertation, University of Economics Ho Chi Minh City, 2016.

[67] Toan, D. L., Phu, H. N., Nhan, V. H., Yen, T. P. H., Tam, Q. N., Anh, N.N. L., Technology Acceptance and Future of Internet Banking in Vietnam. Foresight and STI Governance, Vol. 12, No. 2, 2018, pp. 36 - 49.

[68] Tsai, H., Song, H., \& Wong, K. K. F., Tourism and Hotel Competitiveness Research. Journal of Travel \& Tourism Marketing, 26(5-6), 2009, pp. 522-546.

[69] Vorhies, W.D., Harker. M, The capalities and performance advantages of market - driven firm: An empirical investigation. Australian Journal Of Management (25), 2000, pp. 145172.

[70] $\mathrm{Vu}$ Duong Hoa, Enhancing the Competitiveness of Small \& Medium Textile Exterprises in Vietnam. Economic Doctoral Dissertation, Institute of Trade ResearchMinistry of Industry and Trade, 2017.

[71] $\mathrm{Vu}$ Trong Lam, Enhancing the Competitiveness of the Companies in International Economic Integration, National Politics, Hanoi, 2006.

[72] Wayne F. Cascio, Managing Human Resources: Productivity, Quality Of Work Life, Profits. 8th ed. Part 1, chapter 1, McGraw-Hill Irwin, 2010. 